\title{
Liming Optimizes Nitrogen Fertilization in a Maize-Upland Rice Rotation under No-Till Conditions
}

\author{
Carlos Alexandre Costa Crusciol ${ }^{1, *} \mathbb{1}$, Letusa Momesso ${ }^{1}$, Murilo de Campos ${ }^{1}$, João William Bossolani ${ }^{1}(\mathbb{D}$, \\ José Roberto Portugal ${ }^{1}$, Luiz Gustavo Moretti ${ }^{1}$ (D), Marcelo Raphael Volf ${ }^{2}$, Juliano Carlos Calonego ${ }^{1}$ \\ and Ciro Antonio Rosolem ${ }^{1}$ (D) \\ 1 Department of Crop Science, College of Agricultural Sciences, São Paulo State University (UNESP), \\ Botucatu 18610-034, Brazil; letusamomeso@gmail.com (L.M.); murilodecampos83@gmail.com.br (M.d.C.); \\ bossolani.agro@gmail.com (J.W.B.); jose.portugal@unesp.br (J.R.P.); souzamoretti@gmail.com (L.G.M.); \\ juliano.calonego@unesp.br (J.C.C.); ciro.rosolem@unesp.br (C.A.R.) \\ 2 Department of Agronomy, São Paulo Western University (UNOESTE), Presidente Prudente 19067-175, Brazil; \\ marcelovolf@gmail.com \\ * Correspondence: carlos.crusciol@unesp.br
}

check for updates

Citation: Crusciol, C.A.C.; Momesso, L.; de Campos, M.; Bossolani, J.W.; Portugal, J.R.; Moretti, L.G.; Volf, M.R.; Calonego, J.C.; Rosolem, C.A. Liming Optimizes Nitrogen Fertilization in a Maize-Upland Rice Rotation under No-Till Conditions. Agronomy 2021, 11, 2005. https:// doi.org/10.3390/agronomy11102005

Academic Editor: Frédéric Marsolais

Received: 20 August 2021

Accepted: 27 September 2021

Published: 3 October 2021

Publisher's Note: MDPI stays neutral with regard to jurisdictional claims in published maps and institutional affiliations.

Copyright: (c) 2021 by the authors. Licensee MDPI, Basel, Switzerland. This article is an open access article distributed under the terms and conditions of the Creative Commons Attribution (CC BY) license (https:/ / creativecommons.org/licenses/by/ $4.0 /)$.

\begin{abstract}
Liming and $\mathrm{N}$ fertilization are common practices for optimizing crop yields in tropical agriculture, but the adequate $\mathrm{N}$ rate to ensure crop development, enhance yields and $\mathrm{N}$ use efficiency, and improve soil chemical properties has not been established for grass rotation. We assessed the optimal $\mathrm{N}$ fertilizer rate for combination with liming in an agricultural system composed of two grasses (maize and rice) in rotation under no-till (NT) conditions. Four $\mathrm{N}$ rates $(0,50,100$, and $\left.150 \mathrm{~kg} \mathrm{~N} \cdot \mathrm{ha}^{-1}\right)$ were tested under two liming conditions. Maize $\left(11 \mathrm{Mg} \cdot \mathrm{ha}^{-1}\right)$ and rice $\left(5 \mathrm{Mg} \cdot \mathrm{ha}^{-1}\right)$ yields were highest with lime and $150 \mathrm{~kg} \mathrm{~N} \cdot \mathrm{ha}^{-1}$ applications. At 18 months after liming, lime application increased soil $\mathrm{pH}$. In addition, combining liming with $\mathrm{N}$ fertilization further increased SOM content at all $\mathrm{N}$ rates. Lime increased available $\mathrm{P}$, exchangeable $\mathrm{Ca}^{2+}$ and $\mathrm{Mg}^{2+}$, and $\mathrm{BS}$ at $\mathrm{N}$ rates of 0,50 , and $100 \mathrm{~kg} \mathrm{~N} \cdot \mathrm{ha}^{-1}$. Overall, combining liming and $\mathrm{N}$ fertilization is beneficial for grass crops under NT conditions, as evidenced by enhanced maize and rice $\mathrm{N}$ use efficiency and yields. N fertilization rates of 100 and $150 \mathrm{~kg} \mathrm{~N} \cdot \mathrm{ha}^{-1}$ under lime amendment provided the best improvements in crop yields in this cropping system.
\end{abstract}

Keywords: grass crop rotation; nitrogen rate; tropical agriculture; lime application

\section{Introduction}

Soil acidification and soil nutrient depletion generally lead to stagnant crop yields, especially in areas where the soil has low natural fertility, such as South America and Africa [1,2]. In these regions, liming and application of inorganic $\mathrm{N}$ fertilizers are common agricultural practices for improving soil acidity, optimizing soil chemical characteristics, and enhancing crop yields $[3,4]$. By increasing soil $\mathrm{pH}$ to offset soil acidity, liming improves soil conditions for crop development, enhances crop nutrient uptake, and mitigates soil acidification due to $\mathrm{H}^{+}$release from $\mathrm{N}$ fertilizer. In parallel, efficient $\mathrm{N}$ management in ameliorated soil reduces soil acidification and favors crop development for better yields [5,6]. However, although the effects of liming and $\mathrm{N}$ fertilizer on plant uptake are well known [7-9], the optimal $\mathrm{N}$ rate for amended soil in no-till (NT) systems, especially in grass crop rotation, remains unclear.

NT systems are a viable alternative for minimizing the negative impact of land use and improving the chemical and physical properties of soil [10,11]. The maintenance of crop residues in NT systems reduces the risk of environmental degradation, and the decomposition of the straw neutralizes soil acidity and releases water-soluble organic compounds in the initial stages [12,13]. Moreover, increasing the volume of crop residues by $\mathrm{N}$ fertilizer application promotes the maintenance of moisture in the soil surface and deeper layers and provides a source of nutrients for release in the soil. 
Soil surface liming in association with crop residue maintenance increases $\mathrm{pH}$ and $\mathrm{P}, \mathrm{Ca}^{2+}, \mathrm{Mg}^{2+}$, and $\mathrm{S}-\mathrm{SO}_{4}{ }^{2-}$ availability and minimizes the negative effects of toxic levels of aluminum $\left(\mathrm{Al}^{3+}\right)$ and manganese $(\mathrm{Mn})$ throughout the soil layers [14-16]. The resulting increases in soil microbial activity further promote crop residue decomposition to release nutrients and enhance crop yields [17-19]. However, crop residues only partially replenish soil nutrients, and the application of $\mathrm{N}$ fertilizer in grass crop rotation systems is still necessary to maintain cash crop development and yields [20,21]. N fertilization promotes increased soil organic matter (SOM) and potentiates the effects of liming on plant development, microbial activity, crop residue decomposition, and nutrient cycling.

Cereal crops such as maize and upland rice absorb and export large amounts of $\mathrm{N}$ from soil organic matter (SOM) and litter mineralization. For these high-N-demand crops, $\mathrm{N}$ fertilization plays a particularly essential role in enhancing crop development and yield, but this requirement must be balanced against the risk of negative impacts of excess $\mathrm{N}$ fertilizer application on the environment and grain quality and yield [1,5,22]. In addition, cereal crops typically require $\mathrm{N}$ during a specific crop growth stage [23]. In NT systems, yields of maize and upland rice in rotation vary depending on the sources of nutrients in the soil [24-26]. Crop rotation can increase cash crop yields by improving soil fertility and nutrient replenishment by litter [27], but grass residues have a high $\mathrm{C}: \mathrm{N}$ ratio, leading to microbial $\mathrm{N}$ immobilization [28,29]. Consequently, proper management of $\mathrm{N}$ fertilization is one of the most important management practices for achieving high grain yields in NT rotation systems.

Surface lime application can amend topsoil layers in the short term [30], but the adequate $\mathrm{N}$ fertilizer rate under liming for food production in grass crop rotation systems has not been comprehensively investigated. We hypothesized that combined liming with high rate of $\mathrm{N}$ application would enhance the crop performance, yields, and $\mathrm{N}$ use efficiency of maize and upland rice and reduce the adverse effects of soil acidity in a grass crop rotation system in the short term. Accordingly, the pertinent research questions of the present study were as follows: (i) What are the main changes in nutritional status and yields of maize and upland rice, $\mathrm{N}$ use efficiency, and soil properties in soil amended with lime and $\mathrm{N}$ applications? (ii) What are the main soil and plant properties that influence grain yields of maize and upland rice? (iii) What $\mathrm{N}$ rate combined with liming is adequate to enhance the yields of maize and upland rice in a tropical cropping system with grass rotation?

\section{Materials and Methods}

\subsection{Site Description}

A field experiment was carried out in Botucatu, São Paulo State, Southeastern Brazil $\left(48^{\circ} 25^{\prime} 37^{\prime \prime} \mathrm{W}, 22^{\circ} 49^{\prime} 50^{\prime \prime} \mathrm{S}, 765 \mathrm{~m}\right.$ a.s.l.), under NT conditions for two crop seasons. The soil was classified as a Typic Haplorthox (USDA, 2014) with 500, 140, and $360 \mathrm{~g} \cdot \mathrm{kg}^{-1}$ of clay, silt, and sand, respectively. The climate is Cwa, which corresponds to a humid subtropical zone with dry winters and hot summers according to the Köppen climate classification system. Annual averages at the experimental site are $26.1^{\circ} \mathrm{C}$ in summer, $15.3^{\circ} \mathrm{C}$ in winter, and rainfall of $1360 \mathrm{~mm}$. The rainfall and the mean maximum and minimum temperatures recorded over the two growing seasons are shown in Supplementary Table S1. The chemical properties of the soil were determined $(0.00-0.20 \mathrm{~m})$ before establishing the experiment according to the methodologies described by [31]: $\mathrm{pH} 4.9\left(0.01 \mathrm{~mol} \cdot \mathrm{L}^{-1} \mathrm{CaCl}_{2}\right), 25 \mathrm{~g} \cdot \mathrm{kg}^{-1}$ soil organic matter $(\mathrm{SOM}), 16 \mathrm{mg} \cdot \mathrm{kg}^{-1} \mathrm{P}_{\text {resin }}, 51 \mathrm{mmol}_{\mathrm{C}} \cdot \mathrm{kg}^{-1} \mathrm{H}+\mathrm{Al}, 2.6 \mathrm{mmol}_{\mathrm{C}} \cdot \mathrm{kg}^{-1}$ $\mathrm{K}^{+}, 16 \mathrm{mmol}_{\mathrm{C}} \cdot \mathrm{kg}^{-1} \mathrm{Ca}^{2+}, 10 \mathrm{mmol}_{\mathrm{C}} \cdot \mathrm{kg}^{-1} \mathrm{Mg}^{2+}, 80 \mathrm{mmol}_{\mathrm{C}} \cdot \mathrm{kg}^{-1}$ cation exchange capacity (CEC), and $36 \%$ base saturation (BS). The study area was previously cultivated for 2 years under NT conditions with maize (Zea mays L.) in summer, black oat (Avena strigosa S.) in winter, and pearl millet (Pennisetum glaucum L.) in spring.

\subsection{Experimental Design and Establishment of Treatments}

The experimental design was randomized complete blocks with a $4 \times 2$ factorial scheme with four replications. The treatments consisted of four $\mathrm{N}$ rates applied as side- 
dressing in maize and upland rice rows, i.e., 0 (no N), 50, 100, and $150 \mathrm{~kg} \mathrm{~N} \cdot \mathrm{ha}^{-1}$ as urea, and two levels of soil acidity correction with dolomitic lime, i.e., no lime (-Lime) and $3000 \mathrm{~kg} \cdot \mathrm{ha}^{-1}$ (+Lime). The treatments were applied in two consecutive agricultural years, with maize in the first crop season and upland rice in the second crop season. Between the two crop seasons, pearl millet was grown as a cover crop. The dolomitic lime from EMBRACAL (embracal.com.br) characteristics were $24 \% \mathrm{CaO}, 18 \% \mathrm{MgO}, 90 \%$ equivalent calcium carbonate, and $64 \%$ relative efficiency. Lime was applied in October of the first year by spreading on the soil surface according to [31].

\subsection{Crop Management}

In December of the first year (2 months after lime application), maize (Zea mays L.) (simple hybrid AG9010) was sown at a plant density of 57,000 ha ${ }^{-1}$ in rows spaced $0.45 \mathrm{~m}$ apart (Figure 1). Each plot consisted of ten $6 \mathrm{~m}$ long rows. Fertilization at the time of sowing was conducted according to [32] with $30 \mathrm{~kg} \cdot \mathrm{ha}^{-1} \mathrm{~N}$ as urea, $60 \mathrm{~kg} \cdot \mathrm{ha}^{-1} \mathrm{P}_{2} \mathrm{O}_{5}$ as simple superphosphate, and $50 \mathrm{~kg} \cdot \mathrm{ha}^{-1} \mathrm{~K}_{2} \mathrm{O}$ as potassium chloride. $\mathrm{N}$ rates were applied as side-dressing at the $\mathrm{V}_{6}$ growth stage of maize. Maize was harvested in April of the second year of the experiment.

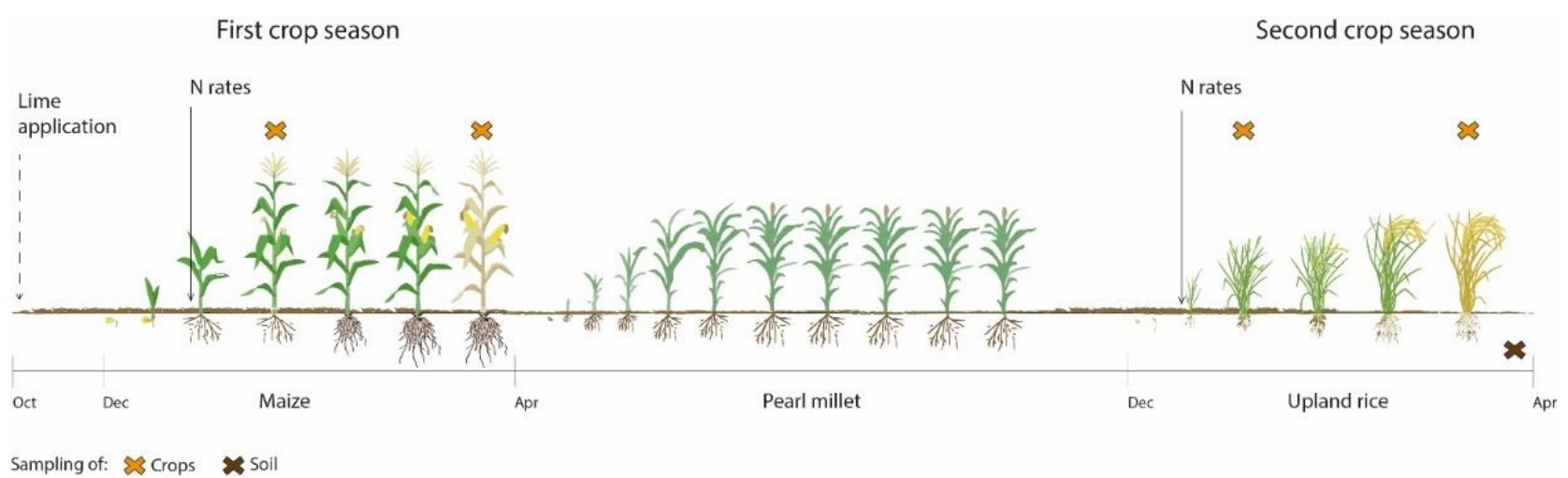

Figure 1. Scheme of $\mathrm{N}$ fertilizer and lime applications and sample collections during two growing seasons (maize and upland rice) of the experiment.

In December of the second year, upland rice (Oryza sativa L.) (cultivar IAC 202) was sown at a seed density of 200 viable seeds $\mathrm{m}^{-2}$ in rows spaced $0.45 \mathrm{~m}$ apart. Fertilizers were applied at the time of sowing according to [32] as $22 \mathrm{~kg} \mathrm{~N} \cdot \mathrm{ha}^{-1}$ as urea, $75 \mathrm{~kg} \mathrm{P}_{2} \mathrm{O}_{5} \cdot \mathrm{ha}^{-1}$ as simple superphosphate, and $45 \mathrm{~kg} \mathrm{~K}_{2} \mathrm{O} \cdot \mathrm{ha}^{-1}$ as potassium chloride. $\mathrm{N}$ rates were manually applied as side-dressing as urea (50\% at the beginning of tillering and $50 \%$ at the time of head differentiation) following the recommendations of [32]. Rice was harvested in April of the subsequent year.

\subsection{Plant Nutritional Status}

Leaf nutrient analysis was performed according to the AOAC (2000) at the full flowering stage for maize (silking) and upland rice (more than $50 \%$ of panicles). $\mathrm{P}, \mathrm{K}, \mathrm{Ca}, \mathrm{Mg}$, and $\mathrm{S}$ were extracted from diagnostic leaves of maize and rice (at the beginning of flowering) by nitroperchloric digestion and determined by atomic absorption spectrophotometry. $\mathrm{N}$ was extracted by sulfuric acid digestion and determined by the Kjeldahl distillation method.

\subsection{Agronomic Parameters, Grain Yield, and N Use Efficiency Indexes}

At the flowering stage, production components were determined for maize (prolificacy, number of grains, and 100-grain weight) and upland rice (panicles per meter, spikelets per panicle, spikelet fertility, and 1000-grain weight).

At the end of the experiment, the maize and upland rice plants were harvested in the useful area of each plot along $4 \mathrm{~m}$ of the four central rows. The harvested plants were 
threshed, and the grains were separated. The grain yield was calculated as $\mathrm{kg} \cdot \mathrm{ha}^{-1}$ and adjusted using a water content of $130 \mathrm{~g} \cdot \mathrm{kg}^{-1}$. The grain crude protein (\%) was calculated by multiplying the grain $\mathrm{N}$ content determined by the Kjeldahl method by 6.5 .

Three indices of $\mathrm{N}$ use efficiency were calculated according to the methods of [33] and [34]: agronomic efficiency (AE), utilization efficiency (UE), and soil N-dependent rate (SNDR). AE was calculated according to the following formula:

$$
\mathrm{AE}(\mathrm{kg} \cdot \mathrm{kg}-1)=(\mathrm{GN}-\mathrm{Gc} / \mathrm{Nr}),
$$

where $G_{N}$ is the cash crop (maize or rice) grain yield of the $N$ fertilized plot $\left(\mathrm{kg} \cdot \mathrm{ha}^{-1}\right), \mathrm{G}_{\mathrm{c}}$ is the cash crop (maize or rice) grain yield in the unfertilized plot (control with no application of $\mathrm{N}$ and no liming), and $\mathrm{N}_{\mathrm{r}}$ is the $\mathrm{N}$ rate applied $\left(\mathrm{kg} \cdot \mathrm{ha}{ }^{-1}\right)$. UE was calculated as follows:

$$
\mathrm{UE}(\mathrm{kg} \cdot \mathrm{kg}-1)=(\mathrm{YN}-\mathrm{Yc} / \mathrm{NN}-\mathrm{Nc}) \times(\mathrm{Nf}-\mathrm{Na} / \mathrm{NN}),
$$

where $Y_{f}$ is the total yield (grain plus dry matter) in the $\mathrm{N}$ fertilized plot $(\mathrm{kg}), \mathrm{Y}_{\mathrm{c}}$ is the total yield in the unfertilized plot (control with no application of $\mathrm{N}$ and no liming) $(\mathrm{kg}$ ), $\mathrm{N}_{\mathrm{N}}$ is the $\mathrm{N}$ accumulation in grain and dry matter in the $\mathrm{N}$ fertilized plot, $\mathrm{N}_{\mathrm{c}}$ is the nutrient accumulation in grain and dry matter $(\mathrm{kg})$ in the unfertilized plot, and $\mathrm{N}_{\mathrm{f}}$ is the $\mathrm{N}$ accumulation by straw and grain of the cash crop in the fertilized plot $(\mathrm{kg})$. UE was calculated separately for maize and rice. Lastly, SNDR was determined according to the following formula:

$$
\operatorname{SNDR}(\%)=(\text { TPNc } / \mathrm{TPNN}) \times 100,
$$

where $\operatorname{TPN}_{\mathrm{c}}$ is the total plant $\mathrm{N}$ accumulated without $\mathrm{N}$ application (control), and $\mathrm{TPN}_{\mathrm{N}}$ is the total plant $\mathrm{N}$ accumulated with $\mathrm{N}$ application. SNDR was calculated separately for maize and rice. No liming was performed in the control treatment.

For upland rice, a $100 \mathrm{~g}$ sample of rice was collected from each plot to determine industrial quality and milled rice productivity. The samples were processed for $60 \mathrm{~s}$ in a mill, and the polished grains were weighed and determined as a percentage. To determine the yields of whole and broken grain, the remaining grains were placed in a $\mathrm{n}^{\circ} 2 \operatorname{trier}(\mathrm{MT}$ model, Suzuki, Santa Cruz do Rio Pardo, Sao Paulo, Brazil) for $30 \mathrm{~s}$ to separate whole from broken grains, which were weighed and reported as percentages. Milled rice productivity was calculated as follows: grain yield $\times$ milling yield $\left(\mathrm{kg} \cdot \mathrm{ha}^{-1}\right)$.

\subsection{Soil Chemical Analysis}

After upland rice harvest (18 months after lime application), eight soil subsamples were sampled randomly from the useful area of each plot for each of the $0.00-0.05,0.05-0.10$, $0.10-0.20$, and $0.20-0.40 \mathrm{~m}$ layers. The samples for a single layer were pooled, dried, sieved ( $2 \mathrm{~mm}$ sieves), and analyzed for $\mathrm{pH}, \mathrm{SOM}, \mathrm{P} \mathrm{K}^{+}, \mathrm{Ca}^{2+}, \mathrm{Mg}^{2+}, \mathrm{BS}$, and aluminum saturation (AS) according to [35]. The remaining samples were stored at $-20^{\circ} \mathrm{C}$ until determination of $\mathrm{NH}_{4}{ }^{+}$and $\mathrm{NO}_{3}{ }^{-}$contents (soil inorganic $\mathrm{N}$ ) by extraction with $\mathrm{KCl}$ and distilled water [36].

\subsection{Analysis of the Results}

The means were subjected to an outlier test followed by evaluation of AndersonDarling normality. Homogeneity was assessed with Levene's test. Normality and homogeneity tests were performed at v20.2 Minitab Statistical Software (Minitab LLC, State College, PA, USA). Subsequently, the means were subjected to analysis of individual variance (ANOVA) by the F test $(p \leq 0.05)$, and, when significant, the means were analyzed by using the $t$-test (Fisher's least significant difference (LSD) at $p \leq 0.05$ ). Heatmaps were constructed using Pearson's correlation coefficients $(p \leq 0.05)$, and only significant correlations are shown. F test and Pearson's correlation were conducted using the agricolae and ggplot2 packages in v4.02 R, Auckland, New Zeland, Microsoft R [37]. 


\section{Results}

\subsection{Maize Crop}

In the first crop season, lime application and side-dress $\mathrm{N}$ rates significantly increased maize leaf concentrations of N, P, K, and S (Table S2 and Figure S1). The leaf concentration of $\mathrm{N}$ was highest when 100 and $150 \mathrm{~kg} \mathrm{~N} \cdot \mathrm{ha}^{-1}$ were applied with liming (Figure S1A). The leaf concentration of $\mathrm{P}$ was higher under liming than without liming. Under liming, the concentration of $\mathrm{P}$ under $150 \mathrm{~kg} \mathrm{~N} \cdot \mathrm{ha}^{-1}$ was only significantly higher than that under $0 \mathrm{~kg} \mathrm{~N} \cdot \mathrm{ha}^{-1}$, whereas, without liming, the concentration of $\mathrm{P}$ was significantly higher under $150 \mathrm{~kg} \mathrm{~N} \cdot \mathrm{ha}^{-1}$ than under 50 and $0 \mathrm{~kg} \mathrm{~N} \cdot \mathrm{ha}^{-1}$ (Figure S1B). Conversely, lime application decreased the leaf concentrations of $\mathrm{K}$ when combined with 0,50 , and $100 \mathrm{~kg} \mathrm{~N} \cdot \mathrm{ha}^{-1}$, and this decrease was accentuated at higher $\mathrm{N}$ rates (Figure S1C). The leaf $\mathrm{S}$ concentration was higher in the treatments with 0 and $50 \mathrm{~kg} \mathrm{~N} \cdot \mathrm{ha}^{-1}$, regardless of liming (Figure S1F). In addition, the leaf concentrations of $\mathrm{Ca}$ and $\mathrm{Mg}$ were higher in the limed treatments than the control (-Lime), regardless of the $\mathrm{N}$ rate (Figure S1D,E).

The interaction of lime application and $\mathrm{N}$ rates had a significant influence on prolificacy, the number of grains per ear, and grain yield, but not 100-grain weight (Table S2 and Figure 2). For 100-grain weight, an effect of $\mathrm{N}$ rates was observed at 100 and $150 \mathrm{~kg} \mathrm{~N} \cdot \mathrm{ha}^{-1}$. Prolificacy was highest in the treatment with lime and $150 \mathrm{~kg} \cdot \mathrm{ha}^{-1}$ of $\mathrm{N}$ fertilizer. The number of grains per ear, grain yield, and grain crude protein were highest when liming was combined with $150 \mathrm{~kg} \mathrm{~N} \cdot \mathrm{ha}^{-1}$. However, regardless of lime application, all parameters were highest at $\mathrm{N}$ fertilizer rates of 100 and $150 \mathrm{~kg} \cdot \mathrm{ha}^{-1}$.

\subsection{Upland Rice Crop}

The leaf concentrations of $\mathrm{N}$ and $\mathrm{P}$ in upland rice were affected by the interaction of lime application and $\mathrm{N}$ rates in the second growing season of the experiment (Table S3 and Figure S2). In the limed treatments, the leaf concentration of $\mathrm{N}$ increased as the $\mathrm{N}$ rate increased and was highest under $150 \mathrm{~kg} \mathrm{~N} \cdot \mathrm{ha}^{-1}$ (Figure S3). In the absence of liming, the leaf concentration of $\mathrm{N}$ did not vary with the $\mathrm{N}$ rate but was higher in the treatments with $\mathrm{N}$ fertilization than in the control. The leaf concentration of $\mathrm{P}$ was similar regardless of the $\mathrm{N}$ rate $\left(0,50,100\right.$, and $\left.150 \mathrm{~kg} \mathrm{~N} \cdot \mathrm{ha}^{-1}\right)$ in the limed treatments, whereas, without liming, the $\mathrm{P}$ concentration was higher when $150 \mathrm{~kg} \mathrm{~N} \cdot \mathrm{ha}^{-1}$ was applied (Figure S3B). No effects of lime application or $\mathrm{N}$ rates were observed for the leaf concentration of K (Table S3 and Figure S3C). Lime application increased leaf $\mathrm{Ca}$ and $\mathrm{Mg}$ concentrations regardless of $\mathrm{N}$ fertilizer application (Figure S3D,E). Under liming, the leaf concentration of S decreased as the $\mathrm{N}$ rate increased, whereas, in the absence of liming, $\mathrm{N}$ rates did not alter the leaf concentration of S (Figure S3F).

The interaction of lime application and $\mathrm{N}$ rates significantly influenced panicles per $\mathrm{m}^{2}$, spikelets per panicle, spikelet fertility, and grain yield of upland rice (Table S3 and Figure 3). An isolated effect of $\mathrm{N}$ rates was observed only for 1000-grain weight (Figure 3D). $\mathrm{N}$ fertilization resulted in higher 1000-grain weight than in the control $\left(0 \mathrm{~kg} \mathrm{~N} \cdot \mathrm{ha}^{-1}\right)$, regardless of the $\mathrm{N}$ rate $\left(50,100\right.$, and $\left.150 \mathrm{~kg} \mathrm{~N} \cdot \mathrm{ha}^{-1}\right)$. Spikelets per panicles did not differ significantly among the $\mathrm{N}$ rates under liming, whereas, without liming, spikelets per panicles were higher under $\mathrm{N}$ fertilization than in the control. Panicles per $\mathrm{m}^{2}$, grain yield, and grain crude protein were greatest under lime application (+Lime) combined with $150 \mathrm{~kg} \mathrm{~N} \cdot \mathrm{ha}^{-1}$. Spikelet fertility was not influenced by $\mathrm{N}$ rates regardless of liming but was lowest in the control treatment with no $\mathrm{N}$ fertilizer or liming. The grain yield increased with the $\mathrm{N}$ rate and was also significantly higher under liming than without liming. 

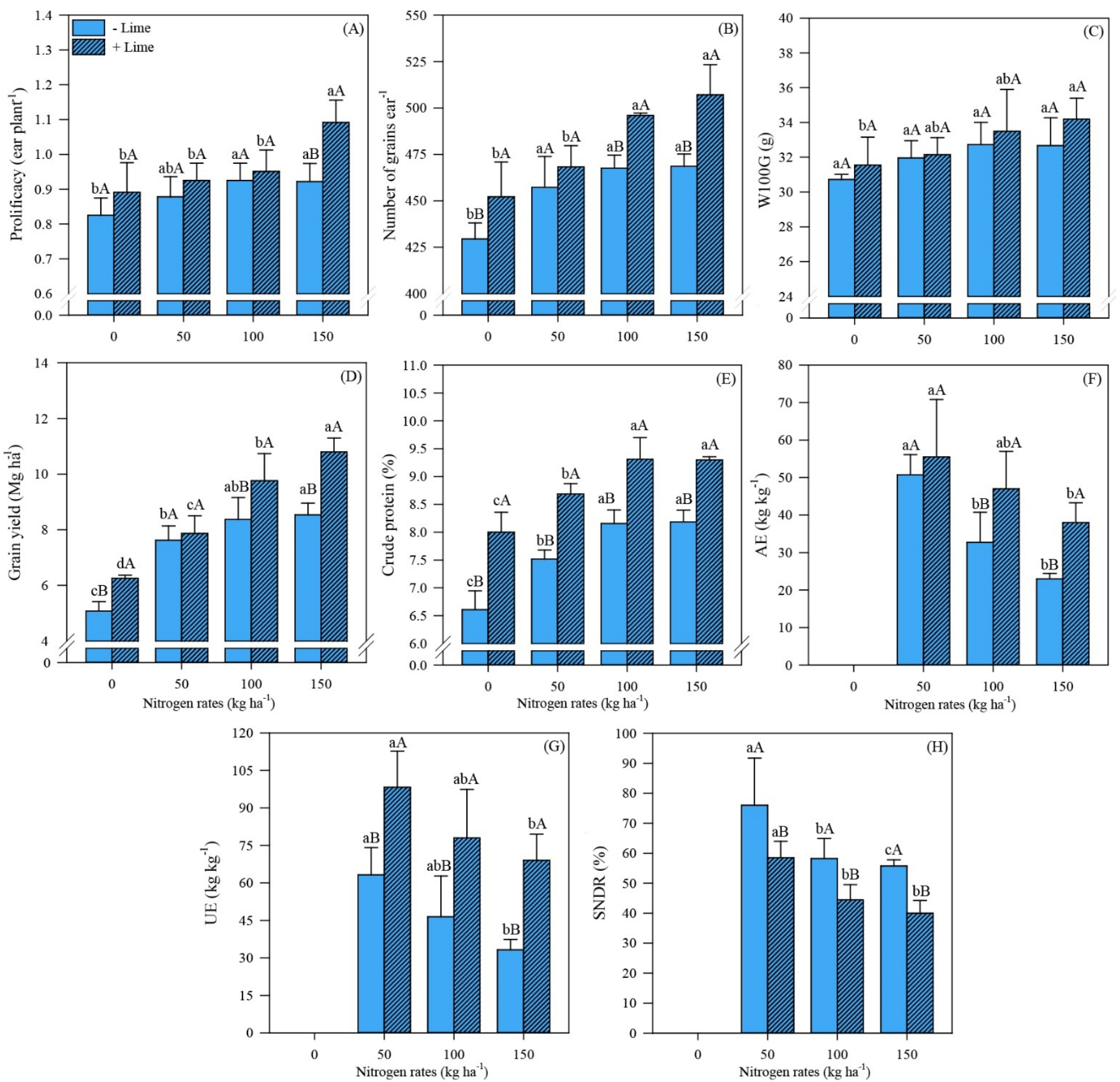

Figure 2. Prolificacy (A), number of grains per ear (B), 100-grain weight (C), grain yield (D), crude protein (E), agronomic efficiency $(\mathbf{F})$, utilization efficiency $(\mathbf{G})$, and soil $\mathrm{N}$-dependent rate $(\mathbf{H})$ of maize under different treatments $(0$ (no $\mathrm{N}$ applied), 50,100 , and $150 \mathrm{~kg} \mathrm{~N} \cdot \mathrm{ha}^{-1} \times$ absence (-Lime) and presence (+Lime) of lime application). Different lowercase and uppercase letters indicate significant differences between $\mathrm{N}$ rates and lime applications, respectively, by Student's $t$-test at $p \leq 0.05$. The error bars express the standard error of the mean $(n=4)$. 

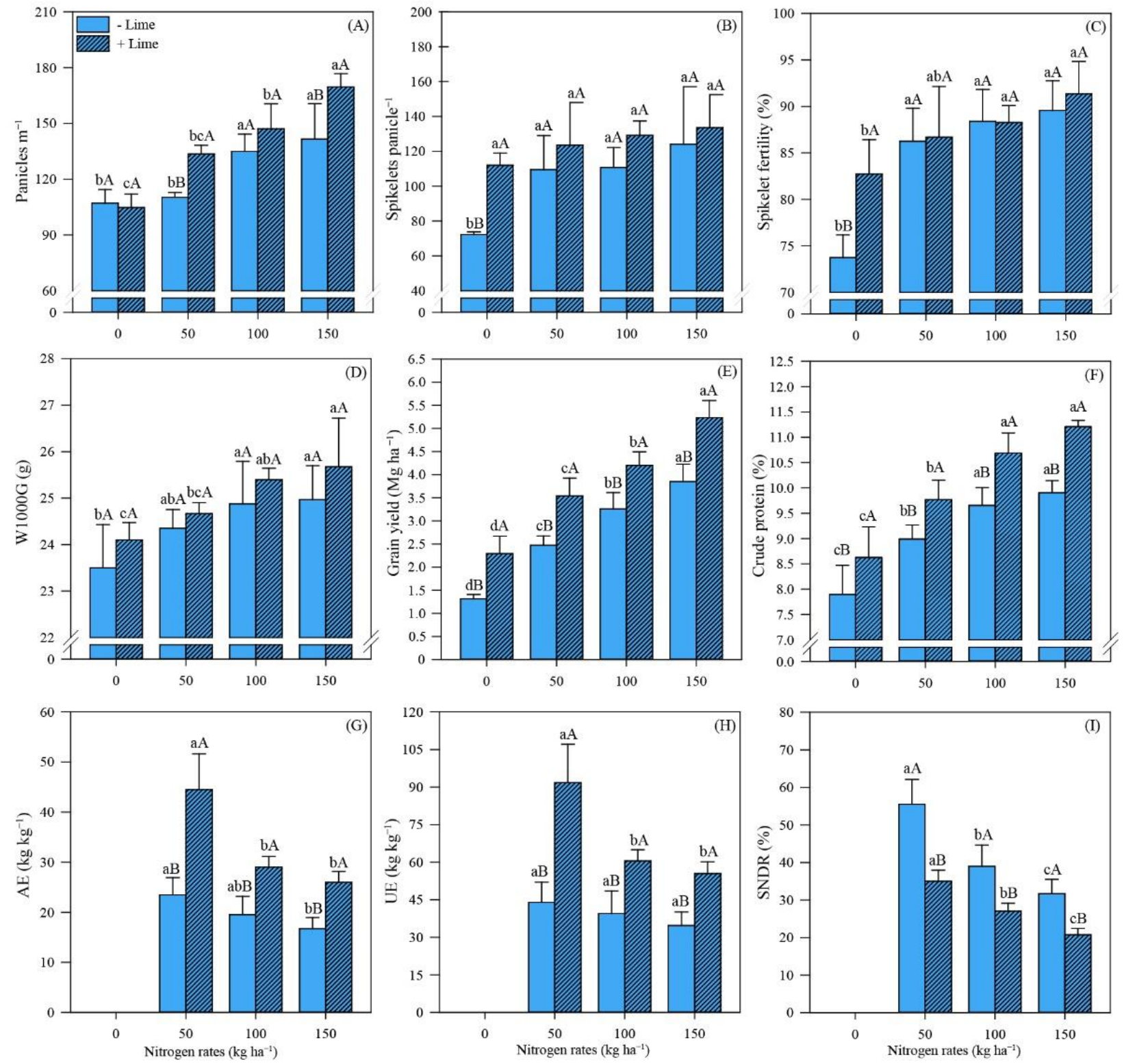

Figure 3. Number of panicles per $\mathrm{m}^{2}$ (A), number of spikelets per panicle (B), spikelet fertility (C), 1000-grain weight (D), and grain yield (E) of upland rice, as well as crude protein $(\mathbf{F})$, agronomic efficiency $(\mathbf{G})$, utilization efficiency $(\mathbf{H})$, and soil $\mathrm{N}$-dependent rate (I) under different treatments (0 (no N applied), 50, 100, and $150 \mathrm{~kg} \mathrm{~N} \cdot \mathrm{ha}^{-1} \times$ absence (-Lime) and presence (+Lime) of lime application). Different lowercase and uppercase letters indicate significant differences between $\mathrm{N}$ rates and lime applications, respectively, by Student's $t$-test at $p \leq 0.05$. The error bars express the standard error of the mean $(n=4)$.

With respect to industrial quality, milled rice productivity was $11.1 \%$ higher when lime was applied compared with no liming, except when $150 \mathrm{~kg} \mathrm{~N} \cdot \mathrm{ha}^{-1}$ was applied (Figure 4). When $150 \mathrm{~kg} \mathrm{~N} \cdot \mathrm{ha}^{-1}$ was applied to ameliorated soil (+Lime), milled rice productivity was $15.8 \%$ higher than in the corresponding treatment without lime application. Milling yield and whole grain yield exhibited similar patterns, whereas no significant differences in broken grain yield were observed among the treatments (Figure 4C). 

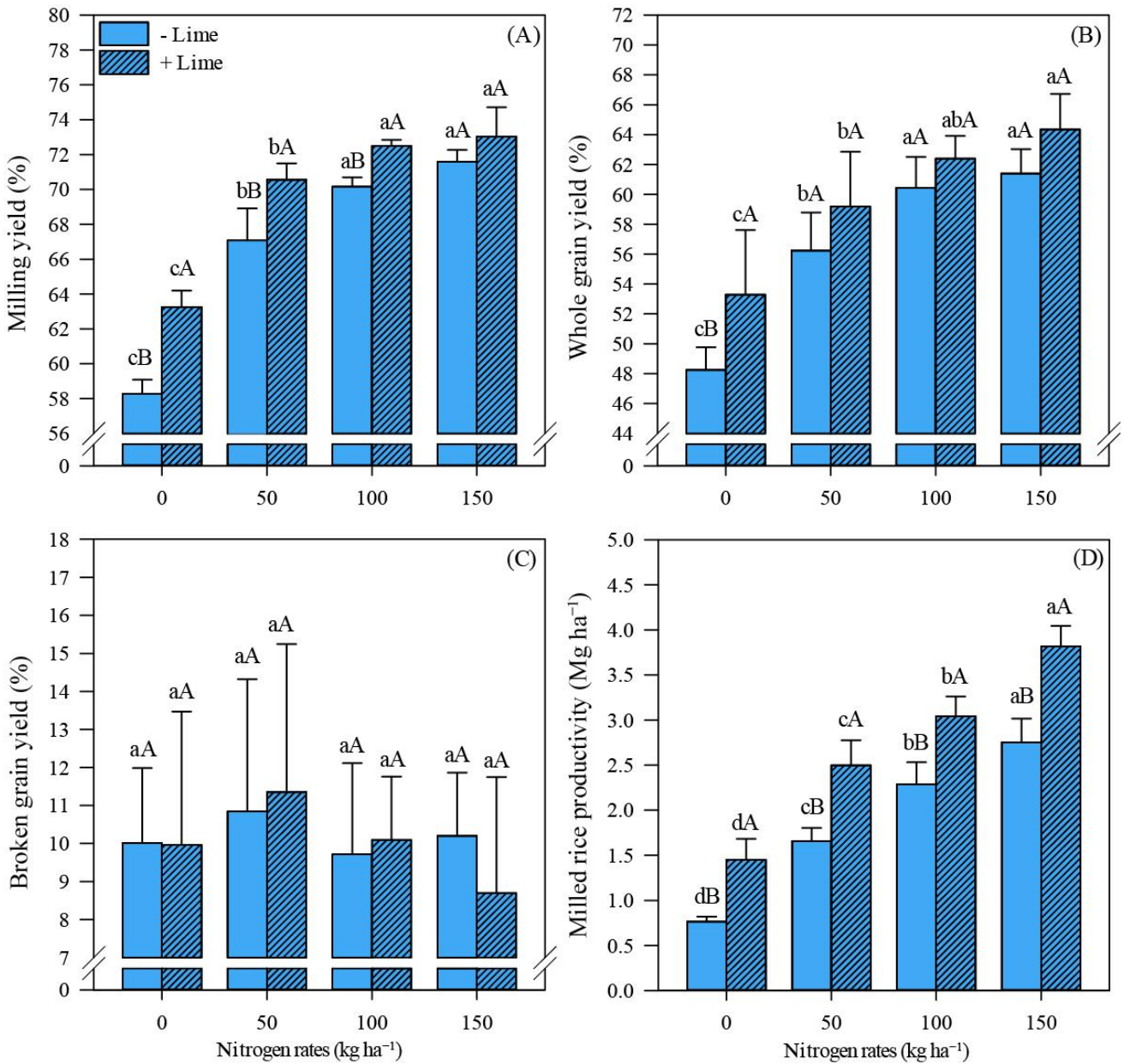

Figure 4. Milling yield (A), whole grain yield (B), broken grain yield (C), and milled productivity (D) of upland rice under different treatments ( 0 (no N applied), 50, 100, and $150 \mathrm{~kg} \mathrm{~N} \cdot \mathrm{ha}^{-1} \times$ absence (-Lime) and presence (+Lime) of lime application). Different lowercase and uppercase letters indicate significant differences between $\mathrm{N}$ rates and lime applications, respectively, by Student's $t$-test at $p \leq 0.05$. The error bars express the standard error of the mean $(n=4)$.

\subsection{Nitrogen Use Efficiency}

For maize and rice cultivated under liming, AE and UE were highest when $50 \mathrm{~kg}$ $\mathrm{N} \cdot \mathrm{ha}^{-1}$ was applied (Figures 2 and 3); for both crops, AE and UE did not differ between the highest $\mathrm{N}$ rates (100 and $\left.150 \mathrm{~kg} \mathrm{~N} \cdot \mathrm{ha}^{-1}\right)$. In the absence of liming, a similar pattern was observed in maize (higher AE at $50 \mathrm{~kg} \mathrm{~N} \cdot \mathrm{ha}^{-1}$ ), whereas, in upland rice, no significant effect of the $\mathrm{N}$ rate on AE or UE was observed (Figures 2 and 3).

The SNDR of maize and rice was significantly affected by $\mathrm{N}$ rates and lime application (Figures 2 and 3). SNDR was significantly higher in all treatments without liming than in those with liming, and SNDR was highest under $50 \mathrm{~kg} \mathrm{~N} \cdot \mathrm{ha}^{-1}$ for both crops.

\subsection{Soil Properties}

At 18 months after liming, soil chemical properties were influenced by the interaction of $\mathrm{N}$ rates and lime application in deeper layers (Figures 5 and 6). Lime application boosted $\mathrm{pH}$, SOM, available $\mathrm{P}$, exchangeable $\mathrm{K}^{+}, \mathrm{Ca}^{2+}$, and $\mathrm{Mg}^{2+}$, and $\mathrm{BS}$ in all soil layers. Soil $\mathrm{pH}$ up to $0.20 \mathrm{~m}$ was highest in the treatment with liming but without $\mathrm{N}$ fertilizer (control) and decreased as the $\mathrm{N}$ rate increased from 50 to $150 \mathrm{~kg} \mathrm{~N} \cdot \mathrm{ha}^{-1}$ (Figure 5A). Regardless of the application of lime, soil $\mathrm{pH}$ was lower under $\mathrm{N}$ fertilizer application. In addition, liming combined with $\mathrm{N}$ application, regardless of the $\mathrm{N}$ rate, resulted in higher SOM content than liming without $\mathrm{N}$ application, except in the uppermost surface layer $(0.00-0.05 \mathrm{~m})$ (Figure 5B). The concentrations of available $\mathrm{P}$, exchangeable $\mathrm{K}^{+}, \mathrm{Ca}^{2+}$, and $\mathrm{Mg}^{2+}$, and BS 
increased with increasing $\mathrm{N}$ rate when lime application was combined with 0,50 , and $100 \mathrm{~kg} \mathrm{~N} \cdot \mathrm{ha}^{-1}$ (Figures 5E and 6A,B,D). By contrast, the concentration of exchangeable $\mathrm{K}^{+}$ was higher under liming but decreased as the $\mathrm{N}$ rate increased (Figure 6A). Lastly, lime application reduced AS regardless of the $\mathrm{N}$ rate (Figure $5 \mathrm{D}$ ), even in deeper soil layers $(0.20-0.40 \mathrm{~m})$.

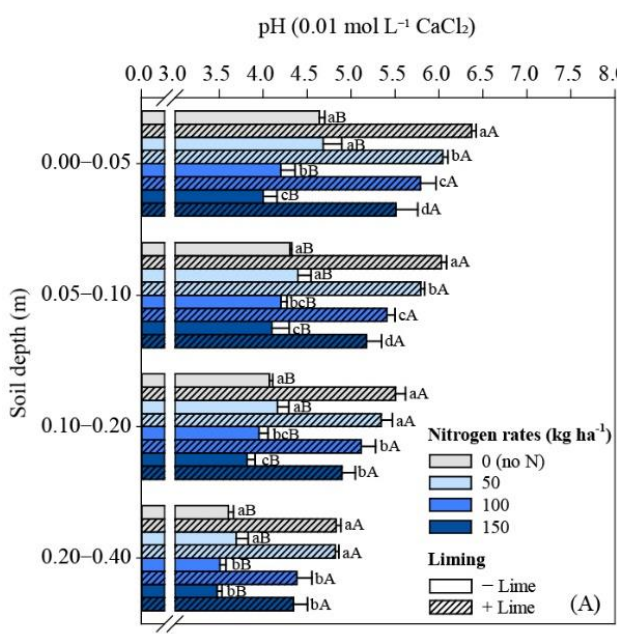

$\mathrm{NH}_{4}{ }^{+}\left(\mathrm{mg} \mathrm{kg}^{-1}\right)$

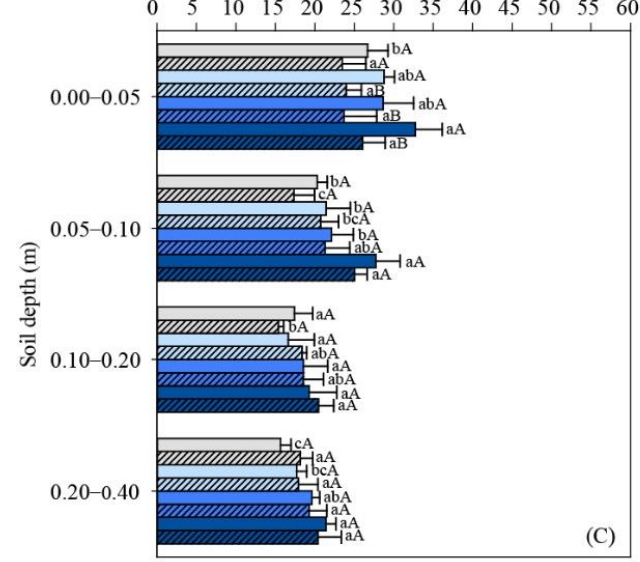

$\mathrm{P}$ resin $\left(\mathrm{mg} \mathrm{kg}^{-1}\right)$

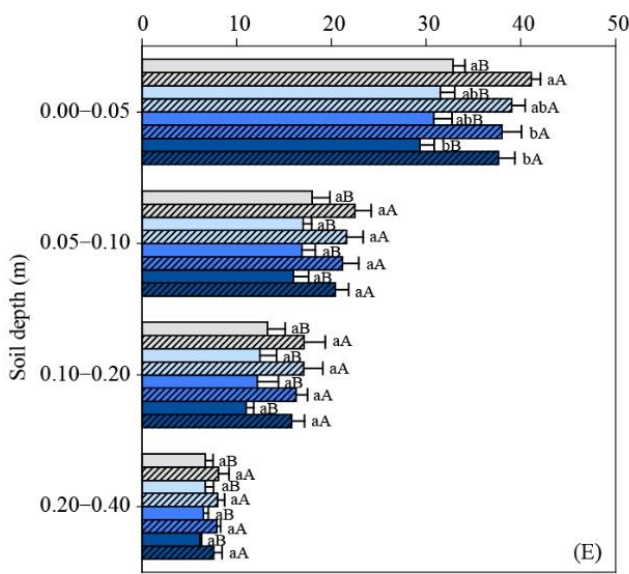

Soil organic matter $\left(\mathrm{g} \mathrm{kg}^{-1}\right)$

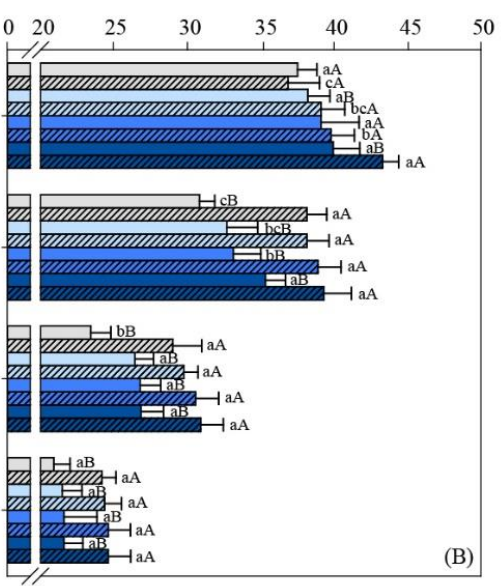

$\mathrm{NO}_{3}{ }^{-}\left(\mathrm{mg} \mathrm{kg}^{-1}\right)$

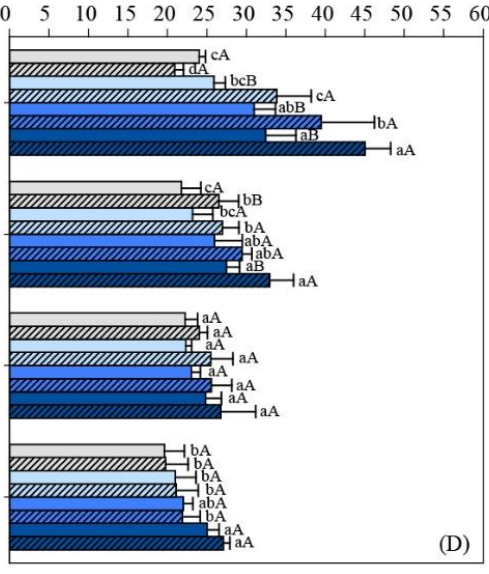

Aluminum saturation (\%)

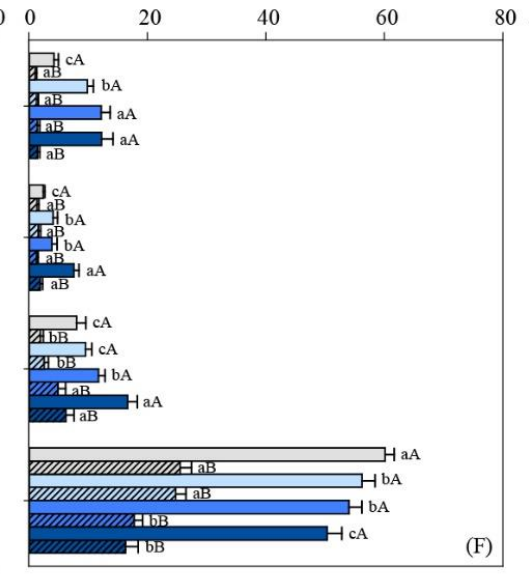

Figure 5. Changes in soil $\mathrm{pH}(\mathbf{A})$, soil organic matter (SOM) (B), $\mathrm{NH}_{4}{ }^{+}(\mathbf{C}), \mathrm{NO}_{3}{ }^{-}(\mathbf{D})$, phosphorus (Presin) (E), and aluminum saturation (AS) (F) under different treatments (0 (no N applied), 50, 100, and $150 \mathrm{~kg} \mathrm{~N} \cdot \mathrm{ha}^{-1} \times$ absence (-Lime) and presence (+Lime) of lime application). Different lowercase and uppercase letters indicate significant differences between $\mathrm{N}$ rates and lime applications, respectively, by Student's $t$-test at $p \leq 0.05$. The error bars express the standard error of the mean $(n=4)$. 

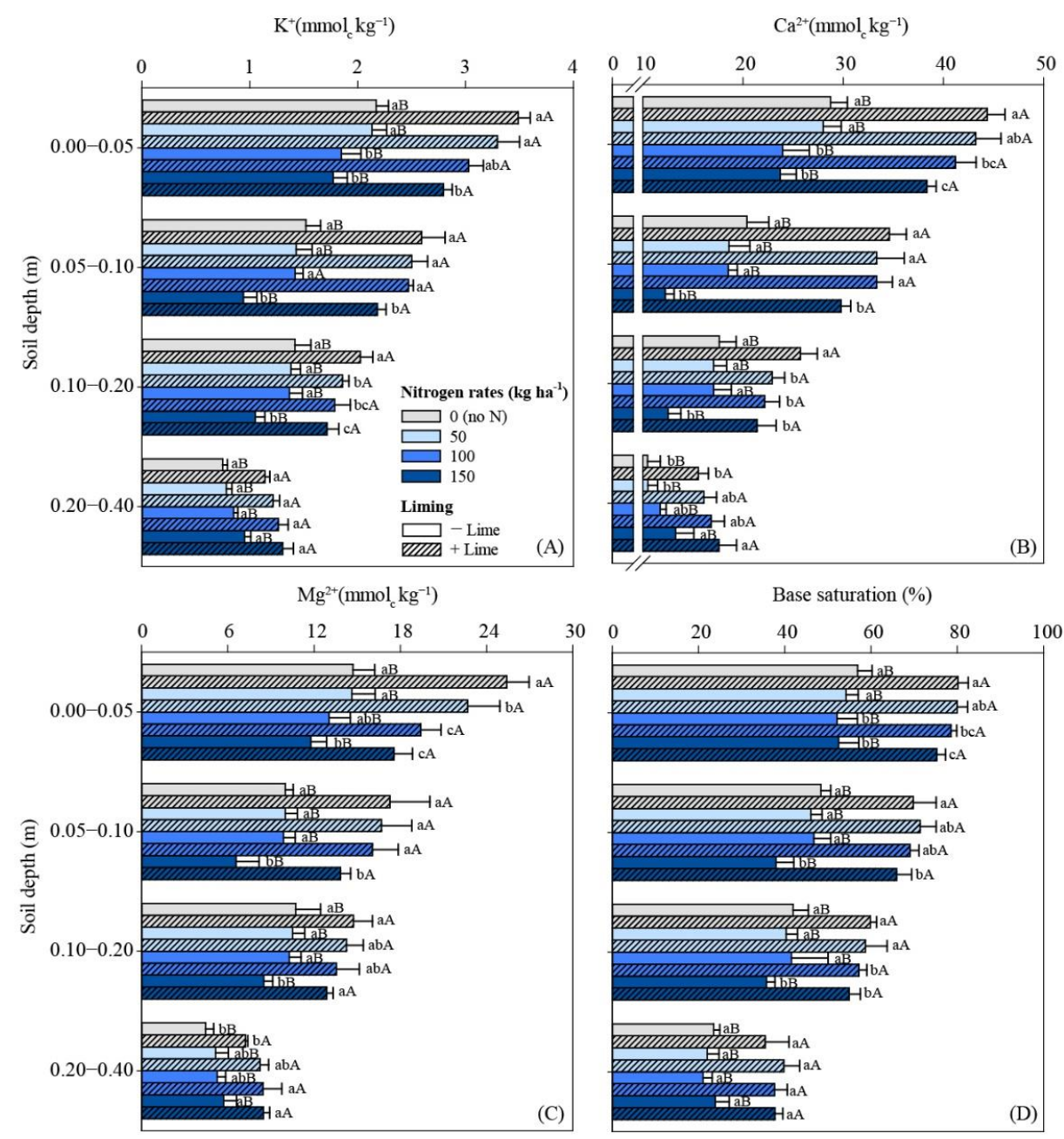

Figure 6. Changes in soil exchangeable $\mathrm{K}^{+}(\mathbf{A}), \mathrm{Ca}^{2+}(\mathbf{B}), \mathrm{Mg}^{2+}(\mathbf{C})$, and base saturation (D) under different treatments ( 0 (no N applied), 50, 100, and $150 \mathrm{~kg} \mathrm{~N} \cdot \mathrm{ha}^{-1} \times$ absence (-Lime) and presence (+Lime) of lime application). Different lowercase and uppercase letters indicate significant differences between $\mathrm{N}$ rates and lime applications, respectively, by Student's $t$-test at $p \leq 0.05$. The error bars express the standard error of the mean $(n=4)$.

\subsection{Pearson's Correlations among All Parameters in the Maize and Upland Rice Crop Seasons}

Correlation analysis of soil properties and the agronomic parameters of maize and upland rice showed that increased soil $\mathrm{pH}$ was associated with improvements in SOM content, available $\mathrm{P}$, exchangeable $\mathrm{Ca}^{2+}$ and $\mathrm{Mg}^{2+}$, and $\mathrm{BS}$, as well as leaf $\mathrm{P}, \mathrm{Ca}$, and $\mathrm{Mg}$ concentrations in maize and upland rice (Figure 7). The improvement in SOM content promoted increases in maize agronomic parameters such as prolificacy, number of grains, 100-grain weight, and grain yield in the first crop season. Similarly, improved SOM content was associated with increased panicles per $\mathrm{m}^{2}$, spikelets per panicle, spikelet fertility, 1000-grain weight, and grain yield in the second crop season. Additionally, the grain yields of maize and upland rice were positively correlated with their leaf concentrations of N, P, and $\mathrm{Ca}$. On the contrary, these agronomic parameters were negatively affected by AS and soil exchangeable $\mathrm{K}^{+}$in both crop seasons. 


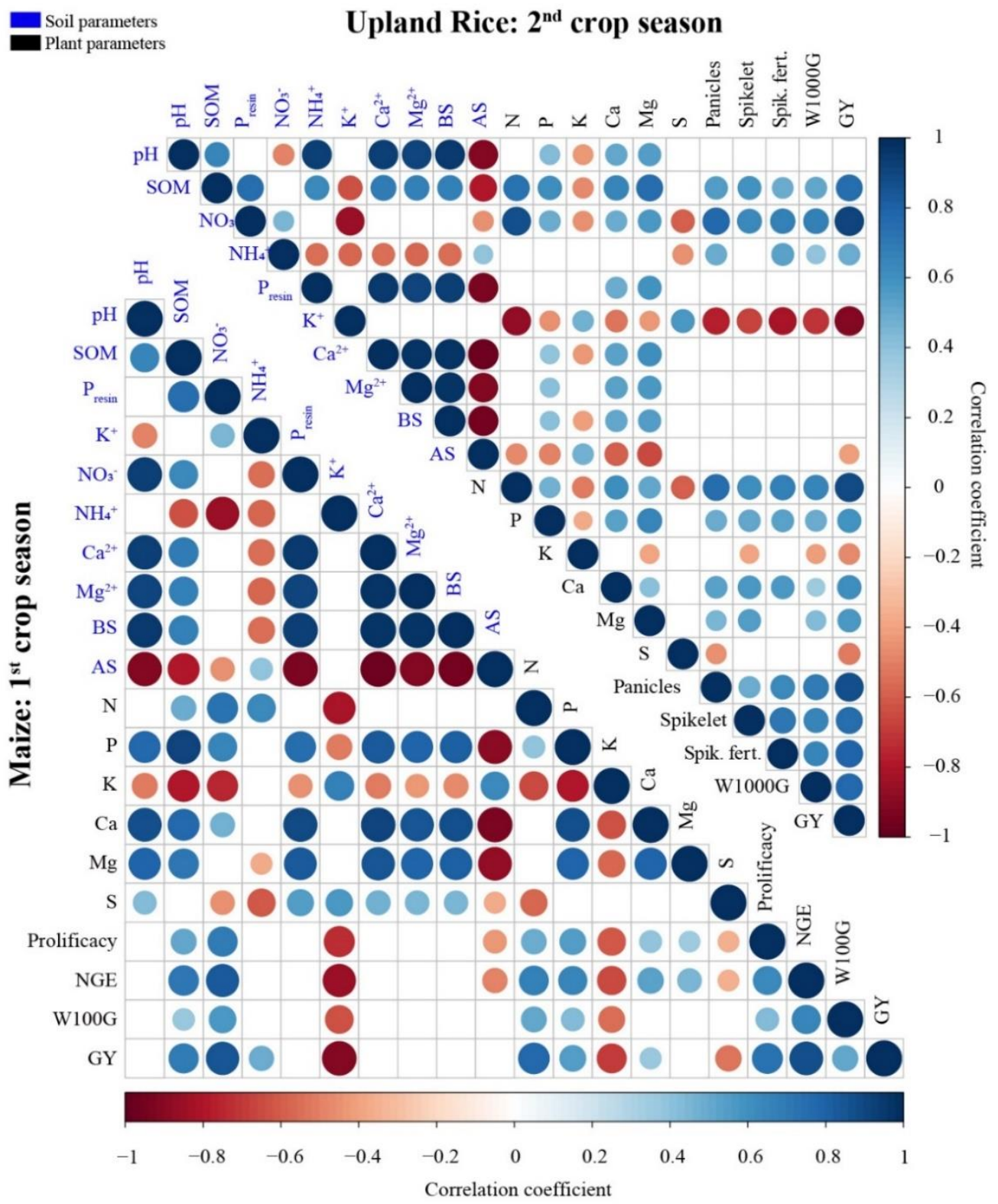

Figure 7. Heatmap of Pearson's correlation based on soil chemical properties and agronomic parameters of maize and upland rice. Only significant correlations at $p \leq 0.05$ are shown.

\section{Discussion}

\subsection{Impact of Liming and N Rates on Maize and Upland Rice}

Nitrogen application management is critical for managing the economic and environmental sustainability of cash crop production, particularly in tropical NT systems with grasses. In the present study, application of the highest $\mathrm{N}$ rate $\left(150 \mathrm{~kg} \cdot \mathrm{ha}^{-1}\right)$ benefited the nutrient status and development of maize by increasing yield components and, consequently, grain yield and crude protein, especially in limed soil. The combination of liming and a high $\mathrm{N}$ rate also increased the availability of $\mathrm{N}$, since surface-applied lime enhances soil $\mathrm{N}$ mineralization and nitrification. Additionally, high $\mathrm{N}$ inputs balance the effect of $\mathrm{N}$ immobilization by soil microbial biomass [38].

Although high $\mathrm{N}$ fertilizer rates can increase soil $\mathrm{pH}$, liming effectively reduced the soil acidity, and no negative effect of higher $\mathrm{N}$ rates on maize was observed. By contrast, the absence of liming in association with $\mathrm{N}$ fertilization negatively impacted crop development and yields (i.e., decreased leaf nutrient concentrations and yield components). These results 
suggest that lower nutrient availability compromises root system development, and that higher soil acidity reduces $\mathrm{N}$ acquisition below the threshold required for plant growth.

Crop rotation in association with surface liming in NT systems influences root system development by improving soil chemical properties, particularly soil $\mathrm{pH}$ and the concentration of $\mathrm{Ca}^{2+}$ [39]. Maize yield was positively correlated with nutrient uptake, as confirmed by the leaf concentrations of N, P and Ca. Liming increased the soil concentrations of $\mathrm{P}$, $\mathrm{Ca}^{2+}$, and $\mathrm{Mg}^{2+}$ by increasing the availability of soil negative charges that can compete with phosphate-specific adsorption and maintain the solubility of these nutrients in the soil solution $[40,41]$. Since $\mathrm{Ca}$ and $\mathrm{Mg}$ are both constituents of lime, liming also has a fertilization effect, which explains the increases in $\mathrm{Ca}^{2+}$ and $\mathrm{Mg}^{2+}$ in the limed treatments [42].

In the second crop season, higher upland rice yields, crude protein, and industrial grain quality were observed at high $\mathrm{N}$ fertilizer rates (100 and $150 \mathrm{~kg} \mathrm{~N} \cdot \mathrm{ha}^{-1}$ ). Systems with exclusive cropping of grasses require additional $\mathrm{N}$ inputs due to plant-microbe competition for available $\mathrm{N}$ in the soil and consequent $\mathrm{N}$ immobilization. In addition, unlike crops such as soybean, grass species lack efficient symbiotic relationships with specific microbes that can fully supply the $\mathrm{N}$ requirement, explaining the response of upland rice to high $\mathrm{N}$ rates.

In this study, pearl millet was used as a cover crop in the off-season (Figure 1) to provide straw for subsequent upland rice. Pearl millet is widely used as a cover crop because it enhances $\mathrm{N}$ use efficiency by the subsequent crop in the short term and has a high rate of litter decomposition (low $\mathrm{C}: \mathrm{N}$ ratio) [43]. Because of the low $\mathrm{N}$ input from pearl millet residues ( $3 \mathrm{Mg} \cdot \mathrm{ha}^{-1}$ of litter), enhanced upland rice yields were only obtained at the highest $\mathrm{N}$ fertilizer rate. The authors of [38] concluded that low $\mathrm{N}$ availability is probably the main limiting factor for rice growth and grain yields. Consistent with this notion, low rice yields were observed when no $\mathrm{N}$ fertilizer was applied, whereas there was a synchronism of rice $\mathrm{N}$ demand and soil $\mathrm{N}$ supply for rice cultivated in soil amended with lime and $\mathrm{N}$ fertilizer.

\subsection{Nitrogen Use Efficiency under Grass Crop Rotation}

In general, reduced soil acidity improved morphological parameters and soil chemical properties for both crops, resulting in enhanced $\mathrm{N}$ uptake and use efficiency. In acidic soils, excess free $\mathrm{Al}\left(\mathrm{Al}^{3+}\right)$ can cause severe damage to the root system, compromising nutrient uptake by plants [12]. Consequently, the neutralization of soil acidity by liming benefited crop $\mathrm{N}$ uptake and use efficiency.

$\mathrm{AE}$ and UE decreased as the $\mathrm{N}$ rate increased, since the increase in the $\mathrm{N}$ rate was not matched by an equivalent increase in grain yield. Nevertheless, the reduced AE and UE were inferior without liming compared to with it, which was consistent with improved $\mathrm{N}$ use efficiency of crops in limed soils.

Taken together, the improvements in these parameters and crop yields highlight the efficiency of combined liming and $\mathrm{N}$ application, particularly when $100 \mathrm{~kg} \mathrm{~N} \cdot \mathrm{ha}^{-1}$ was used for maize and 100 or $150 \mathrm{~kg} \mathrm{~N} \cdot \mathrm{ha}^{-1}$ was used for rice. In addition, the Ca provided by liming resulted in a positive association of $\mathrm{Ca}$ and $\mathrm{NH}_{4}{ }^{+}$to achieve better plant $\mathrm{N}$ use efficiency, as Ca stimulates rapid ammonium absorption in plants, resulting in improved tillering and increased photosynthesis by increasing the Ca: $\mathrm{NH}_{4}$ ratio [44].

The analysis of SNDR revealed that the different soil $\mathrm{pH}$ conditions (- Lime and +Lime) influenced $\mathrm{N}$ uptake from the soil and/or fertilizer. As expected, SNDR was higher in the treatments without liming than in those that received liming. In the vegetative and flowering stages of growth, grasses are extremely dependent on $\mathrm{N}$, which explains the high capacity of these species to absorb great amounts of available $\mathrm{N}$ from the soil [24,45]. The SNDR results showed that most of the $\mathrm{N}$ supply for maize and rice was from $\mathrm{N}$ fertilizer, as the dependence of these crops on $\mathrm{N}$ from the soil decreased as the $\mathrm{N}$ rate increased, particularly when $\mathrm{N}$ fertilization was combined with liming. These results indicate that $\mathrm{N}$ fertilizer recovery is greater in amended soils, probably due to better distribution of the root system. 
In the solid phase of soil, $\mathrm{N}$ is present in both organic $(\sim 95 \%)$ and inorganic forms $\left(\sim 2-5 \% ; \mathrm{NO}_{3}{ }^{-}\right.$and $\left.\mathrm{NH}_{4}{ }^{+}\right)$and may or may not be available to plants [46]. It is unlikely that the $\mathrm{N}$ from $\mathrm{N}$ fertilizer is readily available to plants. However, without $\mathrm{N}$ input, inorganic $\mathrm{N}$ is derived from the decomposition of plant residues by microbial mineralization [17]. Thus, the absence of liming led to crop dependence on soil $\mathrm{N}$, and this dependence increased under lower $\mathrm{N}$ fertilizer rates.

\subsection{Liming and $N$ Rates Affect Soil Properties after Maize and Rice Rotation}

In addition to $\mathrm{BS}$ and $\mathrm{SOM}$ content, most nutrients $\left(\mathrm{P}, \mathrm{Ca}^{2+}, \mathrm{Mg}^{2+}, \mathrm{K}^{+}\right)$were improved by liming. Conversely, AS decreased (Figures 6 and 7). The effect of liming on acidic soils has been comprehensively described in the literature $[42,47,48]$, and liming is an essential practice in tropical agriculture. In particular, liming plays a fundamental role in crop rotation since mineralization of crop residues contributes to soil acidification [49]. In addition, maize and rice remove large amounts of $\mathrm{Ca}$ and $\mathrm{Mg}$ from the soil, which further promotes soil acidification [3].

The effectiveness of surface liming in ameliorating soil acidity in the subsurface layer depends on the vertical transport of $\mathrm{HCO}_{3}{ }^{-}$and/or $\mathrm{OH}^{-}$originating from carbonate hydrolysis [50]. Vertical transport can be influenced by the flow of water into cracks in the soil, soil biopores, or organic acid release [51]. Accordingly, SOM content is an important factor associated with lime reactivity in subsurface soil. Combining ammonium-based fertilizer with liming provides favorable conditions for $\mathrm{N}$ nitrification [52]. Anionic nitrate $\left(\mathrm{NO}_{3}{ }^{-}\right)$can be leached under the high density of soil negative charges caused by liming and carry basic cations via ionic pairs, which explains the higher concentrations of $\mathrm{Ca}^{2+}$ and $\mathrm{Mg}^{2+}$ in deeper layers, even though lime was applied solely on the soil surface. Similar effects were observed for $\mathrm{K}^{+}$. As a monovalent cation, $\mathrm{K}^{+}$can be transported vertically, resulting in lower $\mathrm{K}^{+}$concentrations in the uppermost layers of the soil, especially when high $\mathrm{N}$ rates are applied.

Nitrogen addition also stimulates plant development and, thus, root exploration of deeper soil layers. However, AS can be a chemical barrier to root exploration and is reduced by liming. $\mathrm{Al}^{3+}$ is complexed as Al-hydroxide species via hydrolysis, and this reaction is favored as the $\mathrm{pH}$ of the soil solution increases [53]. Thus, under liming, $\mathrm{Al}^{3+}$ will assume other chemical forms $\left(\mathrm{Al}(\mathrm{OH})^{2+}, \mathrm{Al}(\mathrm{OH})_{2}{ }^{+}\right.$, and $\left.\mathrm{Al}(\mathrm{OH})_{3}\right)$ with minor or no toxicity to plants [54]. Therefore, combining liming with $\mathrm{N}$ application favors root exploration and improved plant uptake capacity.

The positive effects of soil amendment, particularly $\mathrm{N}$ fertilizer, also improved aboveground factors. Grass rotation in this continuous NT system increased the surface content of SOM and benefited the cycling of some essential nutrients at the highest $\mathrm{N}$ rates (100 and $\left.150 \mathrm{~kg} \mathrm{~N} \cdot \mathrm{ha}^{-1}\right)$. The mineralization of cover crop residues was one of the main factors enhancing nutrient input, mainly on the soil surface (Figures S2 and S4). Therefore, N inputs directly determined SOM by increasing biomass and plant litter in this crop rotation system.

\section{Conclusions}

In this grass crop rotation system under $\mathrm{NT}$, applying $\mathrm{N}$ fertilizer to amended soil resulted in efficient $\mathrm{N}$ use and grain production by supplying the continuous $\mathrm{N}$ demand. Although AE and UE decreased as the $\mathrm{N}$ rate increased, combining liming with high $\mathrm{N}$ application benefited agricultural production by increasing nutrient uptake (leaf concentrations of N, P and (a), and crop yields, as well as by improving soil chemical properties and nutrient cycling in short-term crop rotation. SNDR was lower under liming, consistent with the greater $\mathrm{N}$ fertilizer recovery capacity of plants in amended soils. Additionally, liming improved plant nutritional status and soil fertility ( $\mathrm{pH}, \mathrm{SOM}, \mathrm{P}, \mathrm{K}, \mathrm{Ca}$, and $\mathrm{Mg}$ ). For both crops, crop yield was strongly correlated with SOM, soil $\mathrm{N}$ and P content, and leaf $\mathrm{Ca}$ and $\mathrm{Mg}$ concentrations. Overall, we conclude that the use of $\mathrm{N}$ fertilizer at a rate of $150 \mathrm{~kg}$ $\mathrm{N} \cdot \mathrm{ha}^{-1}$ in amended soils enhances crop yields (maize and rice) in this grass crop rotation system. 
Supplementary Materials: The following are available online at https:/ / www.mdpi.com/article/10 .3390/agronomy11102005/s1: Figure S1. Concentrations of nitrogen (A), phosphorus (B), potassium $(C)$, calcium (D), magnesium (E), and sulfur $(F)$ in diagnosis maize leaves under different treatments (0 (no N applied), 50, 100, and $150 \mathrm{~kg} \mathrm{~N} \cdot \mathrm{ha}^{-1} \times$ absence (-Lime) and presence (+Lime) of lime application); Figure S2:.Total dry matter and total $\mathrm{N}$ accumulated in maize under different treatments (0 (no N applied), 50, 100, and $150 \mathrm{~kg} \mathrm{~N} \cdot \mathrm{ha}^{-1} \times$ absence (-Lime) and presence (+Lime) of lime application); Figure S3. Concentrations of nitrogen (A), phosphorus (B), potassium (C), calcium (D), magnesium (E), and sulfur $(\mathrm{F})$ in diagnosis upland rice leaves under different treatments $(0$ (no N applied), 50, 100, and $150 \mathrm{~kg} \mathrm{~N} \cdot \mathrm{ha}^{-1} \times$ absence (-Lime) and presence (+Lime) of lime application); Figure S4. Total dry matter and total $\mathrm{N}$ accumulated in upland rice under different treatments (0 (no $\mathrm{N}$ applied), 50, 100, and $150 \mathrm{~kg} \mathrm{~N} \cdot \mathrm{ha}^{-1} \times$ absence (-Lime) and presence (+Lime) of lime application); Table S1. Means of maximum and minimum temperatures and rainfall during the experiment period; Table S2. Statistical parameters by ANOVA test at $p \leq 0.05$ significance level of experimental factors ( $\mathrm{N}$ rates $\times$ lime application) for maize nutrition and agronomic parameters; Table S3. Statistical parameters by ANOVA test at $p \leq 0.05$ significance level of experimental factors $(\mathrm{N}$ rates $\times$ lime application) for upland rice nutrition and agronomic parameters.

Author Contributions: Conceptualization, C.A.C.C. and C.A.R.; methodology, J.C.C. and L.G.M.; formal analysis, J.W.B. and J.R.P.; data curation, M.R.V.; writing-original draft preparation, L.M. and M.d.C.; writing-review and editing, L.M., M.d.C., and J.W.B.; supervision, C.A.C.C.; funding acquisition, C.A.C.C. All authors have read and agreed to the published version of the manuscript.

Funding: This research was funded by Postgraduate Support Program, the Coordination for the Improvement of Higher Level Personnel (PROAP/CAPES) and the Sao Paulo Research Foundation (FAPESP).

Data Availability Statement: Not applicable.

Acknowledgments: The authors would like to acknowledge the National Council for Scientific and Technological Development (CNPq) for awards for excellence in research to C.A.C.C., J.C.C., and C.A.R.

Conflicts of Interest: The authors declare no conflict of interest.

\section{References}

1. Ladha, J.K.; Dawe, D.; Pathak, H.; Padre, A.T.; Yadav, R.L.; Singh, B.; Singh, Y.; Singh, Y.; Singh, P.; Kundu, A.L.; et al. How Extensive Are Yield Declines in Long-Term Rice-Wheat Experiments in Asia? Field Crop. Res. 2003, 81, 159-180. [CrossRef]

2. Von Uexküll, H.R.; Mutert, E. Global Extent, Development and Economic Impact of Acid Soils. Plant Soil 1995, 171, 1-15. [CrossRef]

3. Caires, E.F.; Haliski, A.; Bini, A.R.; Scharr, D.A. Surface Liming and Nitrogen Fertilization for Crop Grain Production under No-till Management in Brazil. Eur. J. Agron. 2015, 66, 41-53. [CrossRef]

4. Holland, J.E.; Bennett, A.E.; Newton, A.C.; White, P.J.; McKenzie, B.M.; George, T.S.; Pakeman, R.J.; Bailey, J.S.; Fornara, D.A.; Hayes, R.C. Liming Impacts on Soils, Crops and Biodiversity in the UK: A Review. Sci. Total Environ. 2018, 610-611, 316-332. [CrossRef] [PubMed]

5. Fageria, N.K.; Nascente, A.S. Chapter Six-Management of Soil Acidity of South American Soils for Sustainable Crop Production. In Advances in Agronomy; Sparks, D.L., Ed.; Academic Press: Cambridge, MA, USA, 2014; Volume 128, pp. 221-275.

6. Li, Y.; Cui, S.; Chang, S.X.; Zhang, Q. Liming Effects on Soil PH and Crop Yield Depend on Lime Material Type, Application Method and Rate, and Crop Species: A Global Meta-Analysis. J. Soils Sedim. 2019, 19, 1393-1406. [CrossRef]

7. Adams, F.; Martin, J.B. Liming Effects on Nitrogen Use and Efficiency. In Nitrogen in Crop Production; John Wiley \& Sons, Ltd.: Hoboken, NJ, USA, 1984; pp. 417-426. ISBN 978-0-89118-243-6.

8. Mkhonza, N.P.; Buthelezi-Dube, N.N.; Muchaonyerwa, P. Effects of Lime Application on Nitrogen and Phosphorus Availability in Humic Soils. Sci. Rep. 2020, 10, 8634. [CrossRef] [PubMed]

9. Rosolem, C.A. Exchangeable Basic Cations and Nitrogen Distribution in Soil as Affected by Crop Residues and Nitrogen. Braz. Arch. Biol. Technol. 2011, 54, 441-450. [CrossRef]

10. Nascente, A.S.; Stone, L.F. Cover Crops as Affecting Soil Chemical and Physical Properties and Development of Upland Rice and Soybean Cultivated in Rotation. Rice Sci. 2018, 25, 340-349. [CrossRef]

11. Pacheco, L.P.; Monteiro, M.M.S.; da Silva, R.F.; dos Soares, L.S.; Fonseca, W.L.; Nóbrega, J.C.A.; Petter, F.A.; de Alcântara Neto, F.; de Osajima, J.A. Produção de fitomassa e acúmulo de nutrientes por plantas de cobertura no cerrado piauiense. Bragantia 2013, 72, 237-246. [CrossRef] 
12. Martins, A.P.; de Denardin, L.G.O.; Tiecher, T.; Borin, J.B.M.; Schaidhauer, W.; Anghinoni, I.; de Carvalho, P.C.F.; Kumar, S. Nine-Year Impact of Grazing Management on Soil Acidity and Aluminum Speciation and Fractionation in a Long-Term No-till Integrated Crop-Livestock System in the Subtropics. Geoderma 2020, 359, 113986. [CrossRef]

13. Miotto, A.; Tiecher, T.; Kaminski, J.; Brunetto, G.; Conti, L.D.; Tiecher, T.L.; Martins, A.P.; dos Santos, D.R. Soil Acidity and Aluminum Speciation Affected by Liming in the Conversion of a Natural Pasture from the Brazilian Campos Biome into No-Tillage System for Grain Production. Arch. Agron. Soil Sci. 2020, 66, 138-151. [CrossRef]

14. Bossolani, J.W.; dos Santos, F.L.; Meneghette, H.H.A.; Sanches, I.R.; Moretti, L.G.; Parra, L.F.; Lazarini, E. Soybean in Crop Rotation with Maize and Palisade Grass Intercropping Enhances the Long-Term Effects of Surface Liming in No-till System. J. Soil Sci. Plant Nutr. 2020, 21, 119-130. [CrossRef]

15. Crusciol, C.A.C.; Marques, R.R.; Carmeis Filho, A.C.A.; Soratto, R.P.; Costa, C.H.M.; Ferrari Neto, J.; Castro, G.S.A.; Pariz, C.M.; Castilhos, A.M.; Franzluebbers, A.J. Lime and Gypsum Combination Improves Crop and Forage Yields and Estimated Meat Production and Revenue in a Variable Charge Tropical Soil. Nutr. Cycl. Agroecosyst. 2019, 115, 347-372. [CrossRef]

16. Tiritan, C.S.; Büll, L.T.; Crusciol, C.A.C.; Carmeis Filho, A.C.A.; Fernandes, D.M.; Nascente, A.S. Tillage System and Lime Application in a Tropical Region: Soil Chemical Fertility and Corn Yield in Succession to Degraded Pastures. Soil Tillage Res. 2016, 155, 437-447. [CrossRef]

17. Bani, A.; Pioli, S.; Ventura, M.; Panzacchi, P.; Borruso, L.; Tognetti, R.; Tonon, G.; Brusetti, L. The Role of Microbial Community in the Decomposition of Leaf Litter and Deadwood. Appl. Soil Ecol. 2018, 126, 75-84. [CrossRef]

18. Singh, B.-; Rengel, Z. The role of crop residues in improving soil fertility. In Nutrient Cycling in Terrestrial Ecosystems; Marschner, P., Rengel, Z., Eds.; Soil Biology; Springer: Berlin/Heidelberg, Germany, 2007; pp. 183-214. ISBN 978-3-540-68027-7.

19. Ye, X.; Ye, Y.; Chai, R.; Li, J.; Ma, C.; Li, H.; Xiong, Q.; Gao, H. The Influence of a Year-Round Tillage and Residue Management Model on Soil N Fractions in a Wheat-Maize Cropping System in Central China. Sci. Rep. 2019, 9, 4767. [CrossRef] [PubMed]

20. Momesso, L.; Crusciol, C.A.C.; Soratto, R.P.; Tanaka, K.S.; Costa, C.H.M.; Cantarella, H.; Kuramae, E.E. Upland Rice Yield Enhanced by Early Nitrogen Fertilization on Previous Palisade Grass. Nutr. Cycl. Agroecosyst. 2020, 118, 115-131. [CrossRef]

21. Momesso, L.; Crusciol, C.A.C.; Soratto, R.P.; Vyn, T.J.; Tanaka, K.S.; Costa, C.H.M.; Neto, J.F.; Cantarella, H. Impacts of Nitrogen Management on No-Till Maize Production Following Forage Cover Crops. Agron. J. 2019, 111, 639-649. [CrossRef]

22. Tilman, D.; Balzer, C.; Hill, J.; Befort, B.L. Global Food Demand and the Sustainable Intensification of Agriculture. Proc. Natl. Acad. Sci. USA 2011, 108, 20260-20264. [CrossRef]

23. Raun, W.R.; Johnson, G.V. Improving Nitrogen Use Efficiency for Cereal Production. Agron. J. 1999, 91, 357-363. [CrossRef]

24. Crusciol, C.A.C.; Momesso, L.; Portugal, J.R.; Costa, C.H.M.; Bossolani, J.W.; Costa, N.R.; Pariz, C.M.; Castilhos, A.M.; Rodrigues, V.A.; Costa, C.; et al. Upland Rice Intercropped with Forage Grasses in an Integrated Crop-Livestock System: Optimizing Nitrogen Management and Food Production. Field Crop. Res. 2021, 261, 108008. [CrossRef]

25. Crusciol, C.A.C.; Mateus, G.P.; Momesso, L.; Pariz, C.M.; Castilhos, A.M.; Calonego, J.C.; Borghi, E.; Costa, C.; Franzluebbers, A.J.; Cantarella, H. Nitrogen-Fertilized Systems of Maize Intercropped with Tropical Grasses for Enhanced Yields and Estimated Land Use and Meat Production. Front. Sustain. Food Syst. 2020, 4, 256. [CrossRef]

26. Portugal, J.R.; Arf, O.; Buzetti, S.; Portugal, A.R.P.; Garcia, N.F.S.; Meirelles, F.C.; Garé, L.M.; Abrantes, F.L.; Rodrigues, R.A.F. Do Cover Crops Improve the Productivity and Industrial Quality of Upland Rice? Agron. J. 2020, 112, 327-343. [CrossRef]

27. Murphy, R.P.; Montes-Molina, J.A.; Govaerts, B.; Six, J.; van Kessel, C.; Fonte, S.J. Crop Residue Retention Enhances Soil Properties and Nitrogen Cycling in Smallholder Maize Systems of Chiapas, Mexico. Appl. Soil Ecol. 2016, 103, 110-116. [CrossRef]

28. Pan, F.-F.; Yu, W.-T.; Ma, Q.; Zhou, H.; Jiang, C.-M.; Xu, Y.-G.; Ren, J.-F. Influence of 15N-Labeled Ammonium Sulfate and Straw on Nitrogen Retention and Supply in Different Fertility Soils. Biol. Fertil. Soils 2017, 53, 303-313. [CrossRef]

29. Zhang, L.; Zheng, J.; Chen, L.; Shen, M.; Zhang, X.; Zhang, M.; Bian, X.; Zhang, J.; Zhang, W. Integrative Effects of Soil Tillage and Straw Management on Crop Yields and Greenhouse Gas Emissions in a Rice-Wheat Cropping System. Eur. J. Agron. 2015, 63, 47-54. [CrossRef]

30. Ernani, P.R.; Ribeiro, M.F.S.; Bayer, C. Chemical Modifications Caused by Liming below the Limed Layer in a Predominantly Variable Charge Acid Soil. Commun. Soil Sci. Plant Anal. 2004, 35, 889-901. [CrossRef]

31. Van Raij, B.; Cantarella, H.; Quaggio, J.A.; Furlani, A.M.C. Recomedações de Adubação e Calagem Para o Estado de São Paulo, 2nd ed.; Instituto Agronômico (IAC): Campinas, Brazil, 1997.

32. Cantarella, H.; Van Raij, B.; Camargo, C.E.O. Cereals. In Lime and fertilizer recommendations for the State of Sao Paulo; Agronomic Institute of Campinas: Campinas, Brazil, 1997.

33. Fageria, N.K.; Baligar, V.C. Enhancing Nitrogen Use Efficiency in Crop Plants. In Advances in Agronomy; Academic Press: Cambridge, MA, USA, 2005; Volume 88, pp. 97-185.

34. Ye, Q.; Zhang, H.; Wei, H.; Zhang, Y.; Wang, B.; Xia, K.; Huo, Z.; Dai, Q.; Xu, K. Effects of Nitrogen Fertilizer on Nitrogen Use Efficiency and Yield of Rice under Different Soil Conditions. Front. Agric. China 2016, 1, 30-36. [CrossRef]

35. Van Raij, B.; Andrade, J.C.; Cantarella, H.; Quaggio, J.A. Chemical Analysis for Evaluation of Fertility of Tropical Soils; Agronomic Institute of Campinas: Campinas, Brazil, 2001.

36. Keeney, D.R.; Nelson, D.W. Nitrogen-Inorganic Forms. In Methods of Soil Analysis, 2nd ed.; Part 2; Page, A.L., Ed.; ASA, SSSA: Madison, WI, USA, 1982.

37. R Core Team. R: A Language and Environment for Statistical Computing. Available online: http://www.R-project.org/ (accessed on 5 August 2020). 
38. Rosolem, C.A.; Foloni, J.S.S.; de Oliveira, R.H. Nitrogen dynamics in soil as affected by liming and nitrogen fertilization, with straw on the soil surface. Pesqui. Agropecuária Bras. 2003, 38, 301-309. [CrossRef]

39. Leite, G.H.M.N.; Eltz, F.L.F.; Amado, T.J.C.; Cogo, N.P. Atributos químicos e perfil de enraizamento de milho influenciados pela calagem em semeadura direta. Rev. Bras. Ciênc. Solo 2006, 30, 685-693. [CrossRef]

40. De Campos, M.; Antonangelo, J.A.; van der Zee, S.E.A.T.M.; Alleoni, L.R.F. Degree of Phosphate Saturation in Highly Weathered Tropical Soils. Agric. Water Manag. 2018, 206, 135-146. [CrossRef]

41. De Campos, M.; Antonangelo, J.A.; Alleoni, L.R.F. Phosphorus Sorption Index in Humid Tropical Soils. Soil Tillage Res. 2016, 156, 110-118. [CrossRef]

42. Auler, A.C.; Caires, E.F.; Pires, L.F.; Galetto, S.L.; Romaniw, J.; Charnobay, A.C. Lime Effects in a No-Tillage System on Inceptisols in Southern Brazil. Geoderma Reg. 2019, 16, e00206. [CrossRef]

43. Raphael, J.P.A.; Calonego, J.C.; Milori, D.M.B.P.; Rosolem, C.A. Soil Organic Matter in Crop Rotations under No-Till. Soil Tillage Res. 2016, 155, 45-53. [CrossRef]

44. Fenn, L.B.; Taylor, R.M. Calcium Stimulation of Ammonium Absorption in Plants. In Developments in Agricultural and Managed Forest Ecology; Mcmichael, B.L., Persson, H., Eds.; Plant Roots and their Environment; Elsevier: Amsterdam, The Netherlands, 1991; Volume 24, pp. 39-47.

45. Mateus, G.P.; Crusciol, C.A.C.; Pariz, C.M.; Costa, N.R.; Borghi, E.; Costa, C.; Martello, J.M.; Castilhos, A.M.; Franzluebbers, A.J.; Cantarella, H. Corn Intercropped with Tropical Perennial Grasses as Affected by Sidedress Nitrogen Application Rates. Nutr. Cycl. Agroecosyst. 2020, 116, 223-244. [CrossRef]

46. Garbuio, F.J.; Jones, D.L.; Alleoni, L.R.F.; Murphy, D.V.; Caires, E.F. Carbon and Nitrogen Dynamics in an Oxisol as Affected by Liming and Crop Residues under No-Till. Soil Sci. Soc. Am. J. 2011, 75, 1723-1730. [CrossRef]

47. Joris, H.A.W.; Caires, E.F.; Scharr, D.A.; Bini, Â.R.; Haliski, A. Liming in the Conversion from Degraded Pastureland to a No-till Cropping System in Southern Brazil. Soil Tillage Res. 2016, 162, 68-77. [CrossRef]

48. Soratto, R.P.; Crusciol, C.A.C. Atributos químicos do solo decorrentes da aplicação em superfície de calcário e gesso em sistema plantio direto recém-implantado. Rev. Bras. De Ciência Do Solo 2008, 32, 675-688. [CrossRef]

49. Xu, R.K.; Coventry, D.R. Soil PH Changes Associated with Lupin and Wheat Plant Materials Incorporated in a Red-Brown Earth Soil. Plant Soil 2003, 250, 113-119. [CrossRef]

50. Souza, D.M.; Miranda, L.N.; Oliveira, S.A. Soil acidity and its amelioration. In Soil Fertility; Soil Science Brazilian Society: Viçosa, Brazil, 2007; Volume 1, pp. 205-274.

51. Calegari, A.; Tiecher, T.; Hargrove, W.L.; Ralisch, R.; Tessier, D.; de Tourdonnet, S.; de Guimarães, M.F.; dos Santos, D.R. Long-Term Effect of Different Soil Management Systems and Winter Crops on Soil Acidity and Vertical Distribution of Nutrients in a Brazilian Oxisol. Soil Tillage Res. 2013, 133, 32-39. [CrossRef]

52. Bossolani, J.W.; Crusciol, C.A.C.; Leite, M.F.A.; Merloti, L.F.; Moretti, L.G.; Pascoaloto, I.M.; Kuramae, E.E. Modulation of the Soil Microbiome by Long-Term Ca-Based Soil Amendments Boosts Soil Organic Carbon and Physicochemical Quality in a Tropical No-till Crop Rotation System. Soil Biol. Biochem. 2021, 156, 108188. [CrossRef]

53. Hiradate, S. Speciation of Aluminum in Soil Environments. Soil Sci. Plant Nutr. 2004, 50, 303-314. [CrossRef]

54. Li, W.; Johnson, C.E. Relationships among PH, Aluminum Solubility and Aluminum Complexation with Organic Matter in Acid Forest Soils of the Northeastern United States. Geoderma 2016, 271, 234-242. [CrossRef] 